\title{
Designing digital transformation of department educational environment
}

\author{
Irina Z. Kogotkova ${ }^{1^{*}}$, Grigoriy Y. Soroko ${ }^{1}$, Maria N. Guseva ${ }^{1}$, Elena A. Vykhodtseva ${ }^{1}$, and \\ Aleksandr P. Biryukov ${ }^{1}$ \\ ${ }^{1}$ State University of Management, Institute of Industry Management, Department of Project \\ Management, Moscow, Russia
}

\begin{abstract}
Digital transformation of modern educational environment is stipulated by recently occurred changes and intellectualization of information systems of various ecosystems. The aim of this study is development of methodology of design and implementation of digital technologies oriented at integral automation of department educational environment. Using the methods of system analysis, project management and simulation, the content and structure of digital component of this environment were analyzed, aiming at efficient formation of high-quality professional competences of graduates. The experimental results allow to substantiate composition of the required functional units. On the basis of the obtained data, the project concept of department educational environment is proposed, the activity of which is supported by integrated automation system of all information processes. Scientific novelty of the performed study is determined by that the existing automation system of educational environment in fact does not impact department level of information processes. On the basis of analysis of information processes of department level and existing technologies of their automation, a new methodological approach is proposed to conceptualization, development and implementation of fully functional digitalization system of department educational environment. The significance of the proposed approach is comprised of opportunity to integrate digital and content components of educational environment for improvement of education quality.
\end{abstract}

Keywords: educational environment, project management, information process, digital technologies.

\section{Introduction}

The modern concept of requirements to improvement of educational environment is related with massive implementation of digital technologies [1]. This is totally applied to the Russian higher education [2,3].

However, it should be mentioned that the digital educational environment is only a part, a component of the wider notion: educational environment, which includes other constituents in addition to the digital one.

* Corresponding author: izk2005@mail.ru 
The concept content of improvement of educational environment of universities is interpreted differently in each country. The main focus is concentrated at provision of learning flexibility in interactive educational environment, customization of learning, free access to content of any source without any spatial constraints [3-6].

The research objective is the development of methodological approach to design and implementation of technologies oriented at integrated automation of information activity of managers, teachers and staff of departments of Russian universities.

At present, the main focus is concentrated at automation of activities of administrative units, and the tasks solved in departments are affected to minimum [7, 8].

The mentioned preconditions as well as the lack of methodological approaches to conceptualization and development of such projects determined the scientific novelty of this study. It is comprised of the fact that on the basis of analysis of information processes of department level and operating technologies of their automation, the methodological approach is proposed to design fully functional system of digitalization of educational environment of department level in Russian universities.

In accordance with the objective, in the course of the study the following tasks were solved: the content and structure of information processes of department level, as well as the experience of practical implementation were analyzed; methodological approaches and trends of development of digital technologies, aiming at improvement of various areas of activities of Russian universities, were determined.

The functional structure of the model of department digital educational environment has been developed allowing to define the scope of main computer applications required for its efficient operation.

\section{Methods}

The main research hypothesis is based on the assumption that the concept of digital aspect of improvement of university educational environment should provide integrated approach to automation of information activities of university staff, most of whom participate in educational process, as well as in implementation of numerous functions related with organization and management of educational process at department level.

With this aim, it is required to develop fully functional digital systems supporting all areas of department information activities $[9,10]$.

Design and implementation of such systems would allow using the notion of digital educational environment in its modern complete interpretation.

Development of the conceptual model is based on descriptive methodology of construction of automation systems. Herewith, it is important to select the computer technologies used for implementation of the considered model. The stack of the used digital technologies should provide rapid adaptation of the system to changes both regarding the content of organization processes, and development of the applied technologies.

In terms of methodology of project management, formation of digital department educational environment should be based on project approach, since this process is characterized by unique objective, limited resources, including those regarding time. The project sequence in accordance with the methodology of the project management should include the main stages of project lifetime, namely: conceptualization, development, and implementation.

At the conceptualization stage, the design principles are developed and structural properties of digital department educational environment are defined. The development stage stipulates for decomposition of working structure, results and sequence of technological process of subject area. The implementation stage is the process of 
achievement of project objectives, that is, fulfilment of works using the scheduled resources.

\section{Results}

The proposed conceptual model includes a series of interrelated functional units providing integrated automation of main information processes of department level, both educational and administrative.

At present, the following composition of functional units is proposed in the frames of the proposed conceptual model of digital department educational environment.

1. Knowledge database of subject area of the department: the base containing knowledge of the department specialization.

2. The unit of methodological support: the unit maintaining implementation of creation, arrangement, and use of working programs of disciplines.

3. The unit of support of learning process: the unit providing access to content of department disciplines. It can be supplemented by functionality required for implementation of distance learning.

4. The unit of scheduling of learning process: the system of calendar planning integrating all areas of its activity and providing its smooth work.

5. The unit of document flow: integration of system of university document flow and various documents of department, which are formed using standard office software.

6. The unit of regulatory management: the system of regulation of current work providing efficient monitoring of its execution.

7. The unit of management of project activity.

8. Department executes activities of nonfunctional character. In this regard, it would be reasonable to supplement the integrated system of department management with the unit aimed at management of project activity of the department.

9. The unit of current management: it is intended for adjustment of external impacts and their coordination with the main processes of department level.

10. The unit of personal profiles: the set of personal profiles of all users of the system providing opportunity to address to department database, formation of content for the units supporting learning process.

\section{Discussion}

During the study the available publications on the respective subject have been analyzed [1, $2,4,6,7,11-13$ ], as well as the information obtained by the authors during analysis of digital educational environment in departments of State University of Management and Moscow Architectural Institute (State Academy) [9, 10, 14].

Analysis of the published results of digitalization implementation in some Russian universities $[8,11,12,14,15]$ has demonstrated that at present there are no automation systems oriented at demands of implementation of information processes of department level.

In order to provide high quality automation of information activity of departments, even higher level of customization of project solutions is required.

Designing of digital department educational environment in terms of project management at various stages of its lifecycle has not been discussed in scientific publications; however, the authors believe that this trend is promising both in terms of development of methods of project management and in terms of practical applicability for 
projects of digital educational environment of departments of humanitarian and engineering disciplines.

\section{Conclusion}

At present, digitalization of department activity is not carried out systemically, the functionality related with department educational environment is implemented to minimum. Mostly this can be attributed to the absence of works devoted to scientific substantiation of composition and content of functionality of subsystems required for its creation. This work has attempted to form conceptual model of such system as well as of project approach to its development and implementation.

Practical verification of the proposed conceptual model performed in cooperation with several departments of Russian universities $[9,14]$ has confirmed expedience of further studies and developments in this area.

\section{References}

1. M. Zeng, Harvard Business Review Press, September-October, 88-96 (2018). Accessed on: October 15, 2020. [Online]. Available: https://hbr.org/2018/09/alibabaand-the-future-of-business

2. M.A. Abrosimova, A.V. Zakharov, Bulletin USPTU. Science, education, economy. Series economy, 4(18), 125-131 (2016)

3. A.A. Sidorova, Smart-tekhnologii v vysshem obrazovanii [Smart technologies in higher education] (2017). Accessed on: October 15, 2020. [Online]. Available: http://www.library.fa.ru/exhib.asp?id=199

4. C. Heinemann, V.L. Uskov, Smart university: literature review and creative analysis, in V.L. Uskov, J.P. Bakken, R.J. Howlett, and L.C. Jain (Ed.), Smart universities. concepts, systems and technologies, 11-46 (Springer International Publishing AG, 2018). https://doi.org/10.1007/978-3-319-59454-5_2

5. B. Sadia, A. Amjad, Journal of Applied Research in Higher Education, 9(4), 550-564 (2017). https://doi.org/10.1108/JARHE-11-2016-0077

6. V.L. Uskov, J.P. Bakken, S.Karri, A.V. Uskov, C.Heinemann, and R. Rachakonda, Smart university: conceptual modeling and systems' design, in V.L. Uskov, J.P. Bakken, R.J. Howlett, L.C. Jain (Ed.), Smart universities, smart innovation, systems and technologies, 49-86 (Springer International Publishing AG, Cham, 2018). https://doi.org/10.1007/978-3-319-59454-5_3

7. A.A. Aletdinova, A.A. Melnichenko, Yugra State University Bulletin, 352(37), 14-16 (2015)

8. V.V. Petrova, M.N. Luppian, Model' SMART kafedry universiteta [SMART model of the university department] (2014). Accessed on: October 15, 2020. [Online]. Available: http://www.nizrp.narod.ru/metod/kaffiniuch/8

9. F.N. Korshakov, et al., Sistema kompleksnoy avtomatizatsii uchebnoy deyatel'nosti vuza [The system of complex automation of educational activities of the university], in Proceedings of the forum "Tsifrovyye tekhnologii v inzhenernom obrazovanii: novyye trendy i opyt vnedreniya" [Digital technologies in engineering education: new trends and implementation experience], 28-29 November 2019, Moscow, Russia, 168-171 (2019) 
10. Proceedings of the 31 st conference Sovremennyye informatsionnyye tekhnologii $\mathrm{v}$ obrazovanii [Modern information technologies in education], 2-3 July 2020, TroitskMoscow, Russia (2020)

11. E.N. Babin, Universitetskoe Upravlenie: Praktika i Analiz, 22(6), 44-54 (2018). https://doi.org/10.15826/umpa.2018.06.057

12. G.A. Mavlyutova, Ekonomicheskaya Bezopasnost i Kachestvo, 3(32), 5-7 (2018)

13. E.A. Khalimon, M.N. Guseva, I.Z. Kogotkova, and I.S. Brikoshina, Digitalization of the Russian economy: first results, European production of social and behavioural sciences, in Proceedings of the International scientific and practical conference "Global challenges and prospects for the development of modern economy", 57, 199-213 (2018)

14. I.Z. Kogotkova, G.Ya. Soroko, Kastomizatsiya tsifrovykh tekhnologiy organizatsionnogo upravleniya [Customization of digital technologies of organizational management], in Proceedings of the 3rd international forum "Shag v budushcheye: iskusstvennyy intellekt i tsifrovaya ekonomika: Smart Nations: ekonomika tsifrovogo ravenstva" ["Step into the future: artificial intelligence and the digital economy: smart nations: the economy of digital equality"], 9-10 December 2019, Moscow, Russia, 141-152 (2020)

15. N.I. Romancheva, Tsifrovoy universitet kak element tsifrovoy ekosistemy obrazovaniya [Digital University as an Element of the Digital Education Ecosystem], in Proceedings of the forum "Tsifrovyye tekhnologii v inzhenernom obrazovanii: novyye trendy i opyt vnedreniya" ["Digital technologies in engineering education: new trends and implementation experience"], 28-29 November 2019, Moscow, Russia, 166-168 (2019) 